\title{
Poszukiwanie dobrego życia na globalnym Południu. Migranci w nieformalnym sektorze turystycznym w Indiach
}

\section{Abstract}

\section{Searching for a Good Life in the Global South. Migrants In the Informal Tourism Sector in India}

\begin{abstract}
Migration motivated by searching for a good life is usually associated with the privileged citizens of the Global North. This is even more apparent if we look at the intersections of migration and tourism. These are usually 'expatriates' from the Global North in the Global South who fulfill their quest running lifestyle oriented small tourism businesses. Meanwhile, migrants who originate from the Global South are imagined as homo economicus, motivated predominantly by better earning opportunities. I challenge this assumption by scrutinizing the informal tourism sector at the Hampi World Heritage site in India. The majority of small entrepreneurs in this sector are seasonal migrants. When asked about the reasons for choosing Hampi, they point at the category of shanti (i.e. tranquility), which they use to counter capitalist notions of profitability. I seek to answer the question of how 'tranquility' is defined by them and how this affects their migratory decisions.
\end{abstract}

Keywords: good life, aspirations, migration, informal tourism sector, India, Hampi, Goa

Migracje kierowane wyborem stylu życia (lifestyle migration) są zwykle postrzegane jako przywilej obywateli krajów tzw. globalnej Północy; „poszukiwanie osobistego spełnienia przez [osoby] zamożne i geograficznie mobilne" (Benson, O’Reilly 2016: ix). Te skojarzenia są jeszcze bardziej ewidentne na przecięciach migracji i turystyki, gdy mowa o przedsiębiorczości związanej ze stylem życia w turystyce (lifestyle entrepreneurship in tourism; Ateljevic, Doorne 2000). 
To zwykle tak zwani ekspaci z globalnej Północy w krajach globalnego Południa są w stanie spełnić swoje marzenie o innym, lepszym życiu, prowadząc drobną przedsiębiorczość ukierunkowaną na styl życia w sektorze turystycznym, określaną mianem LOST (lifestyle oriented small tourism; Carlsen, Morrison, Weber 2008). Często wykorzystują w tym celu globalne nierówności ekonomiczne oraz kapitał społeczny i kulturowy związany z pozycją klasową. Z kolei migranci pochodzący z krajów globalnego Południa są najczęściej wyobrażani jako homo oeconomicus, kierujący się w swoich decyzjach migracyjnych głównie możliwością wyższych zarobków. W tego rodzaju wyobrażeniach styl życia i dobre życie to elitarne kategorie klasowe.

W tym artykule pragnę wyjść nie tylko poza binarne postrzeganie mobilności motywowanej wyborem stylu życia i migracji ekonomicznych, ale i poza dychotomię globalnej Północy i globalnego Południa w sposobie, w jaki myślimy o mobilności globalnie. Chcę pokazać, że poszukiwanie dobrego życia (good life), czyli satysfakcji z życia nieredukowalnej wyłącznie do wysokości dochodu i materialnego standardu (Fischer 2014: 201), jest również ważną motywacją dla migrantów z/w krajach globalnego Południa. Studium przypadku, za pomocą którego zamierzam dowieść tej tezy, stanowi nieformalny sektor turystyczny w Indiach oraz pracujący w nim migranci sezonowi. Skupię się na wiosce Hampi w południowym stanie Karnataka, wpisanej na listę światowego dziedzictwa UNESCO, gdzie zrealizowałam etnograficzne badania terenowe ${ }^{1}$. Większość dostawców usług turystycznych w Hampi to drobni, mobilni przedsiębiorcy, zarówno z Indii, jak i z krajów sąsiednich (głównie z Nepalu i Tybetu), którzy przyjeżdżali do Hampi na okres pięciu, sześciu miesięcy w sezonie zimowym (mniej więcej od października do marca). Zapytani o powody wyboru tego konkretnego miejsca, wskazywali przede wszystkim kategorię spokoju (shanti), ewidentnie nie aspirując do maksymalizacji zysku. W artykule próbuję odpowiedzieć na pytanie, co

1 Projekt badawczy nr 2016/20/S/HS3/00085 finansowany ze środków Narodowego Centrum Nauki. W ramach badań towarzyszyłam pracownikom sektora turystycznego $\mathrm{w}$ ich codziennych praktykach, wywołując w rozmowach $\mathrm{z}$ nimi refleksje na temat podjętych decyzji migracyjnych, w rezultacie uzyskując dane biograficzne o ich mobilnych życiach (pytając na przykład, dlaczego nie wybrali innych popularnych miejscowości turystycznych; zob. Gillen 2011). Obserwowałam też ich wzajemne stosunki z mieszkańcami Hampi, którzy wynajmowali im lokale na działalność biznesową i/lub pokoje mieszkalne, oraz relacje $\mathrm{z}$ turystami. Badania te zostały zrealizowane w roku 2017 w trakcie dwóch dwumiesięcznych pobytów terenowych - od stycznia do marca oraz od października do grudnia (choć teren ten był mi znany, gdyż w latach 2013 i 2014 realizowałam tam inne kilkumiesięczne badania; zob. np. Bloch 2016; Bloch 2018). W 2017 roku w Hampi żyło około 800 mieszkańców. Trudno oszacować liczbę sezonowych migrantów, ponieważ nie widnieją oni $\mathrm{w}$ żadnych rejestrach, ale mniej więcej $1 / 3$ rodzin we wiosce wynajmowała pomieszczenia, dachy lub pokoje przyjezdnym drobnym przedsiębiorcom. W trakcie kilku miesięcy badań, czyli codziennego, intensywnego i powtarzalnego przesiadywania w sklepikach, na straganach, na zapleczach restauracji i w recepcjach, dotarłam do ponad $40 \mathrm{z}$ nich. Było to więc umiejscowione badanie zjawiska mobilności (Salazar, Elliot, Norum 2017: 9-11; zob. też Coates 2017). 
rozumieli pod tym pojęciem oraz w jaki sposób wpływało ono na ich migracyjne decyzje i praktyki.

\section{Nieformalny sektor turystyczny w Hampi}

Hampi wpisane na listę UNESCO to pozostałości po hinduskim królestwie Widźajanagaru, które obejmowało cały południowy Półwysep Indyjski między XIV a XVI wiekiem. To również ważny cel pielgrzymek, ze świątynią Wirupaksza, poświęconą bogu Śiwie, mieszczącą się w sercu wioski. Ruiny pałaców, budowli sakralnych i fortyfikacji wpisują się w spektakularny krajobraz naturalny, który tworzą olbrzymie otoczaki, plantacje bananowców i palm kokosowych oraz meandrująca, święta rzeka Tungabhadra. Co więcej, uważa się, że to właśnie tam znajdowało się małpie królestwo z eposu Ramajana - jednego z dwóch największych dzieł literatury hinduskiej (zob. Fritz, Michell 1991; Verghese 2002; Kotraiah 2008; Fritz, Michell 2014). Hampi i jego okolice to zatem uświęcony krajobraz, a liczne festiwale odbywające się na przestrzeni roku przyciągają tłumy pielgrzymów z regionu (Das 1996).

Choć hippisi „odkryli” Hampi już w latach 70. XX wieku - jedno z kultowych miejsc tamtych czasów, Goa, znajduje się w odległości zaledwie 350 kilometrów - to zagraniczni turyści w większych liczbach zaczęli trafiać do wioski dopiero w latach 90. Było to wynikiem zarówno umieszczenia Hampi na liście UNESCO w roku 1986, jak i rosnącej popularności backpackingu w Indiach w ostatniej dekadzie XX wieku. W owym czasie w Hampi nie było żadnej infrastruktury turystycznej, w związku z czym mieszkańcy zaczęli stopniowo odchodzić od niskodochodowego rolnictwa - tym bardziej że większość z nich nie posiadała ziemi na własność, a jedynie najmowała się do prac rolnych - i przekształcać swoje domostwa w małe, rodzinne biznesy: kilkupokojowe guest house'y, niewielkie lokale gastronomiczne, sklepiki czy drobne punkty usługowe.

Rozwój sektora turystycznego wkrótce przyciągnął sezonowych migrantów z różnych regionów Indii, a także z Nepalu i Tybetu, specjalizujących się w obsłudze turystów. Nepalczycy zdominowali branżę gastronomiczną, prowadząc restauracje serwujące francuską zupę cebulową i meksykańskie enchiladas. Tybetańczycy, których przodkowie osiedlili się w północnych Indiach w wyniku handlu przygranicznego i pielgrzymek, sprzedawali buddyjskie posążki i makatki z sentencjami Dalajlamy. Migranci wewnętrzni z Radżastanu - indyjskiego stanu położonego półtora tysiąca kilometrów od Hampi - prowadzili sklepy z ręcznie wytwarzaną biżuterią, tkaninami i wyrobami skórzanymi. Kobiety z grupy Lambani - określanej jako „Cyganie Indii” (zob. Burman 2010; Naik 2010) - specjalizowały się w handlu odzieżą. Część z tych osób - głównie Tybetańczycy, Nepalczycy i Lambani - migrowała zwykle z rodzinami, w innych przypadkach była to migracja męska (drobny przedsiębiorca, czasem prowadzący biznes z partnerem 
lub zabierający z sobą kilku pomocników). Hampi obsługiwało głównie indywidualnych, dysponujących ograniczonym budżetem turystów z globalnej Północy, do których stopniowo zaczęli dołączać młodzi przedstawiciele indyjskiej klasy średniej.

Sytuacja uległa zmianie w roku 2011, kiedy to władze okręgowe, wraz z Archaeological Survey of India (państwową instytucją archeologiczną) oraz stanowym Wydziałem Turystyki rozpoczęły chaotyczną akcję „regulowania” turystyki w Hampi poprzez ograniczenie sektora nieformalnego, czyli w praktyce wysiedlanie mieszkańców oraz wyburzanie ich domów i lokali usługowych. $\mathrm{W}$ oficjalnej narracji, reprodukowanej przez urzędników i sympatyzujące z nimi media, miały one zagrażać integralności zabytków (zob. Bloch 2016; Bloch 2017a). Najpierw usunięto mieszkańców z głównego bazaru prowadzącego do świątyni Wirupaksza, a w kolejnym roku wyburzono część znajdującą się między świątynią a rzeką. W roku 2013 wyburzenia ustały. To „przestrzenne czyszczenie” (Herzfeld 2006), prowadzone pod pretekstem ochrony materialnego dziedzictwa kulturowego i w celu rozwijania formalnego sektora turystycznego w oddalonym o 12 kilometrów mieście Hospet, doprowadziło do znacznego skurczenia się wioski (z pierwotnej liczby około 2500 mieszkańców pozostała 1/3). Wywołało również stan swoistej liminalności, gdyż plany władz w stosunku do pozostałej części wioski nie są znane jej mieszkańcom ani ich najemcom - bohaterom tego artykułu. Stąd narracje o kategorii spokoju rozwijane były w obliczu realnej możliwości jego końca. Mimo to życie w Hampi w trakcie moich badań toczyło się dalej - z początkiem października pojawiali się turyści, a wraz z nimi mobilni pracownicy nieformalnego sektora turystycznego (zob. Bloch 2017b).

Rozwój turystyki w Hampi można zatem uznać za klasyczny przykład wyłaniania się nieformalnego sektora turystycznego w wyniku oddolnych, nieplanowanych inicjatyw. Rozgraniczenie na sektor formalny i nieformalny w turystyce wprowadził Erik Cohen (1982), odróżniając w ten sposób małe, rodzinne przedsięwzięcia operujące głównie w systemie gotówkowym i oferujące nieformalne zatrudnienie, od dużych, zestandaryzowanych usługodawców typu kurorty all-inclusive należące do potężnych krajowych potentatów lub ponadnarodowych firm (zob. Oppermann 1993). Sektor nieformalny jest uważany za bardziej inkluzywny głównie dlatego, że nie tworzy barier w dostępie do turysty i jego kapitałów (np. pod postacią formalnego wykształcenia) i gwarantuje, że większość pieniędzy wydawanych przez turystów trafia bezpośrednio do lokalnych usługodawców, ograniczając w ten sposób zjawisko określane w literaturze jako leakage ( $\mathrm{z}$ ang. dosł. wyciek; zob. Wilson 1997). To właśnie ten sektor najczęściej pada ofiarą państwowych projektów modernizacji, których oficjalnym celem jest regulowanie, normalizowanie i standaryzowanie (zob. Bloch 2018: 321-322). 


\section{Kategoria spokoju}

Sezonowi, drobni przedsiębiorcy w nieformalnym sektorze turystycznym w Hampi - choć z pozoru migranci czysto ekonomiczni - pytani przeze mnie o powody wyboru tego konkretnego miejsca w większości wskazywali korzyści pozaekonomiczne. Innymi słowy nie postrzegali zysku jako swojej głównej motywacji. Wszyscy byli zgodni co do tego, że robiąc biznesy na Goa - o wiele bardziej popularnym i lukratywnym kierunku turystycznym - z pewnością zarobiliby więcej. I rzeczywiście, wielu miało za sobą doświadczenie pracy na goańskich plażach. Wybrali jednak Hampi, ponieważ - jak twierdzili - „tu jest shanti”. Zdanie to powtarzane było przez moich rozmówców niczym mantra. Termin shanti (sanskr. Śantih) można tłumaczyć jako „spokój”. Możliwość prowadzenia biznesu w sposób niespieszny i zrelaksowany wydawała się głównym kryterium satysfakcji, dużo wyżej wartościowanym niż możliwość uzyskania wysokiego zarobku. Co dokładnie oznaczała ta kategoria dla sezonowych migrantów w Hampi i jak spokojne/dobre życie było przez nich praktykowane?

Po pierwsze, pojęcie shanti było w sposób naturalny wiązane $\mathrm{z}$ bliskością świątyni Wirupaksza i ogólnie świętym charakterem miejsca. Wytwórca biżuterii z Radżastanu zwykł mawiać, że „lubi miejsca świątynne, ponieważ mają dobrą energię". Nepalski właściciel restauracji przeniósł swój biznes z Goa do Hampi, „ponieważ tutaj jest spokojnie [shanti], blisko świątyni”. Ciekawe jest to, że argument ów był podnoszony przez wszystkich migrantów niezależnie od ich wyznania, w tym przez buddystów i muzułmanów. Co więcej, ograniczenia związane ze świętością miejsca, mające znaczenie zwłaszcza w przypadku prowadzenia restauracji - takie jak zakaz sprzedaży niewegetariańskich potraw i alkoholu czy obowiązek zamykania wszystkich lokali przed godziną 21.00 - nie były wskazywane jako jakaś istotna niedogodność. Pytani - hipotetycznie - o plany na przyszłość na wypadek całkowitego zlikwidowania możliwości świadczenia usług turystycznych w Hampi, moi rozmówcy brali pod uwagę inne „świątynne miejsca”.

Po drugie, wiejski charakter Hampi również był często wskazywany przez migrantów jako przyczyna ich wyboru. Żaden z nich nie rozważał przeniesienia działalności biznesowej do pobliskiego miasta Hospet, choć to tam władze usilnie próbowały przekierować ruch turystyczny. Hospet było zgodnie opisywane jako „brzydkie, zatłoczone i głośne”. Powolne tempo życia w Hampi, jego oddalenie od głównych szlaków komunikacyjnych, prawie całkowity brak samochodów i taksówek oraz dużych hoteli wymieniano jako cechy gwarantujące spokój. Również niezwykły krajobraz był przedstawiany w rozmowach o Hampi jako źródło wyciszenia. Wielu moich partnerów badawczych miało zwyczaj chodzić na wczesnoporanne spacery, ćwiczyć jogę nad brzegiem rzeki lub na dachu wynajmowanego lokalu czy pływać wieczorami. Podobnie postrzegały swoje miejsce pracy kobiety zatrudnione jako pokojówki i kelnerki w nadmorskim kurorcie turystycznym w postsocjalistycznej Bułgarii, będące bohaterkami książki The Red Riviera. 
Gender, Tourism, and Postsocialism on the Black Sea autorstwa Kristen Ghodsee (2005). Zatrudnienie w sektorze turystycznym dawało im możliwość przebywania w przyjemnym miejscu - które przeciwstawiały pracy w biurze - w otoczeniu „szczęśliwych ludzi na wakacjach”. Jedna z pokojówek stwierdziła wręcz, że „gdyby była lekarką, musiałaby cały czas mieć do czynienia z cierpiącymi, zatroskanymi ludźmi" (Ghodsee 2005: 64).

Po trzecie, o poczuciu spokoju decydowały dobre relacje z miejscową ludnością. Mieszkańcy Hampi wynajmowali lokale na sezonową działalność w sektorze turystycznym prowadzoną przez migrantów. Rozwiązanie to wydawało się satysfakcjonujące dla obu stron: mieszkańcy Hampi, mniej kompetentni w biznesie (na przykład w kwestii źródeł zaopatrzenia), woleli regularne i stabilne dochody, które uzyskiwali z czynszu, niż ryzyko związane z samodzielnym prowadzeniem działalności gospodarczej ( $\mathrm{z}$ wyjątkiem rodzinnych pensjonatów i biur podróży, w przypadku których mogli się opierać na lokalnych sieciach społecznych - autorikszarzach dostarczających klientów do guest house’ów czy przewodnikach turystycznych). Właściciele lokali i ich najemcy byli najczęściej związani z sobą przez lata, co rodziło poczucie zażyłości (na przykład miejscowe kobiety, które wynajmowały Nepalczykowi dach swojego domu na restaurację, pomagały przy narodzinach obu jego córek i wspierały jego żonę w połogu). W rezultacie migranci opisywali mieszkańców Hampi jako „dobrych ludzi, którzy nie przysparzają problemów osobom z zewnątrz”, „nie są zbyt zamożni, a więc uczciwi”, „są przyjaźni”, nie wykorzystują swojej pozycji (czyli bycia „miejscowym”) i nie wywyższają się. Co ciekawe, relacje pomiędzy mieszkańcami a migrantami wydawały się znacznie lepsze niż relacje pomiędzy samymi mieszkańcami wioski, w których dominowały zazdrość i nieufność (w dużej mierze wywołane poczuciem niepewności w związku z wyburzeniami i wysiedleniami).

\section{Kapitalistyczna dżungla}

Wszystkie powyższe spostrzeżenia były formułowane przez porównanie z Goa, które najwyraźniej stanowiło główny punkt odniesienia dla sezonowych migrantów w Hampi. Jeśli chodzi o relacje z miejscową ludnością, mieszkańców Goa określano jako skupionych wyłącznie na generowaniu zysków, wręcz chciwych, a przez to amoralnych: „zepsutych”, tych, którzy „piją i palą [haszysz], i gonią tylko za pieniędzmi”. Często słyszałam opowieści o ciągłym podwyższaniu czynszów, wyłudzeniach i ogólnie złym traktowaniu migrantów. W narracjach moich rozmówców Goa jawiło się jako kapitalistyczna dżungla, która wyraźnie ich przerażała. Wiedzieli, że aby w niej przetrwać, musieliby pracować dłużej i ciężej, pod większą presją i w społecznie nieprzyjaznym środowisku. Zwłaszcza dwie kwestie powracały w rozmowach o Goa: konieczność opłacania prowizji oraz działalność lokalnej „mafii”. 
W przypadku bardziej masowych, zorganizowanych i krótkoterminowych form turystyki na Goa płacenie prowizji przewodnikom grup turystycznych za przyprowadzanie klientów do sklepów czy restauracji było powszechną praktyką. W Hampi proceder ten był właściwie nieobecny. Turyści indywidualni, długoterminowi i dysponujący niewielkim budżetem - głównie tak zwani plecakowicze (backpackers) - sami decydowali, co i gdzie kupić, mając duże doświadczenie zdobyte w czasie często wielomiesięcznych podróży po kraju. Co więcej, często spędzali czas, przesiadując na straganach, w sklepikach i w restauracjach, gawędząc $\mathrm{z}$ ich właścicielami (o Indiach, o swoich krajach pochodzenia, o życiu, o sprawach globalnych), co pozwalało obu stronom wyjść poza czysto rynkową relację klientusługodawca. Budowane w ten sposób poczucie bliskości dawało drobnym przedsiębiorcom możliwość pozycjonowania się w relacji partnerskiej wobec turystów: jako przyjaciele, gospodarze, eksperci od własnej kultury czy nawet obrońcy (na przykład autorikszarz broniący turystek singielek przed nachalnością mężczyzn; zob. Bloch 2018: 152-175).

Nieformalny sektor turystyczny tworzy bowiem, jak je nazwał Tim Edensor (1998: 41-68, 149-180), heterogeniczne przestrzenie turystyczne (heterogeneous tourist spaces), w których możliwe jest rozwijanie relacji wychodzących poza kapitalistyczną wymianę. W przeciwieństwie do przestrzeni enklawowych (enclavic tourist spaces) obie strony turystycznego kontaktu nie są tu od siebie oddzielone, a „tubylcy” nie występują wyłącznie w roli usługodawców bądź atrakcji turystycznych (zob. idea „raju kontrolowanego" Grahama Danna 1996). W odróżnieniu od enklaw w sektorze formalnym, który opiera się na ekonomicznej wydajności, przewidywalności i standaryzacji usług, drobni przedsiębiorcy sektora nieformalnego, nienadzorowani przez menedżerów, mają większą swobodę w zakresie rozwijania relacji z turystami i zarządzania swoim czasem (mogą na przykład pozwolić sobie na kilkudniowe zamknięcie sklepu i udanie się na wycieczkę z zaprzyjaźnionym turystą). Co więcej, rodzinne biznesy zacierają granice pomiędzy sferą publiczną i prywatną, umożliwiając turystom wgląd w codzienność. Jeden ze sprzedawców tak ukazywał różnice między sektorem formalnym (na przykładzie miasta Hospet) i nieformalnym w Hampi:

Do Hampi trafiają ostatnio bogaci ludzie, którzy nocują w [luksusowych] hotelach w Hospet. Ale oni wręczają nam pieniądze, jakbyśmy byli żebrakami [jako ilustrację mój rozmówca wykonał ręką gest rzucania pieniędzy na ladę]. Po drugiej stronie [rzeki w Hampi] turyści są inni, mili, usiądą z tobą, pogadają z tobą, zapalą z tobą. To jest prawdziwa turystyka!

Wszystko to umożliwia pracownikom sektora nieformalnego nawiązywanie bezpośrednich i bliskich relacji z turystami, będących źródłem dywersyfikacji sieci społecznych i wzmacniania kompetencji międzykulturowych (zob. Bloch 2018). Często kapitał społeczny i kulturowy uzyskiwany w wyniku takich spotkań był porównywany przez moich partnerów badawczych do podróżowania, co można interpretować jako travelling-in-dwelling, czyli podróżowanie w zamiesz- 
kiwaniu (Clifford 1992: 108): cieszenie się różnorodnością świata bez konieczności fizycznego przemieszczania się. W ten sposób pracownicy sektora turystycznego - tak często postrzegani w przeciwieństwie do kosmopolitycznych turystów jako osiadli nosiciele klarownej, „tradycyjnej” tożsamości - również uczestniczą w świecie mobilnych znaczeń i idei, rzucając wyzwanie binarnej opozycji zakorzenienia w terytorium i kulturze i kosmopolitycznej otwartości (zob. Glick Schiller, Irving 2014). Drobni przedsiębiorcy z Hampi rozdzielali zatem społeczną wartość ich pracy od materialnego zysku, bardzo doceniając tę pierwszą.

Drugą kwestią wskazywaną przez nich jako zasadnicza wada sektora turystycznego na Goa była obecność lokalnej „mafii”. Wielokrotnie słyszałam, że „mafia” ta wyłudza pieniądze od sezonowych przedsiębiorców w zamian za „ochronę”, czyli prawo do prowadzenia działalności turystycznej. Dotyczy to nawet małych biznesów, takich jak obnośna sprzedaż chust czy taniej, sztucznej biżuterii na plażach, zwykle prowadzona przez kobiety z grupy Lambani. Te wędrowne sprzedawczynie znajdują się w szczególnie podatnej na nadużycia sytuacji, będąc uwięzionymi pomiędzy lokalną „mafią” a często skorumpowaną policją, która pod pretekstem zwalczania praktyk narzucania się turystom organizuje naloty na plaże. Kobiety Lambani, które pracowały na Goa, zanim przeniosły swoje mikrobiznesy do Hampi, opowiadały mi, że wiele razy musiały uciekać przed policją, a gdy im się to nie udawało, ich towar był konfiskowany (potem mogły go odkupić od policjantów pod pretekstem zapłacenia kary). Fakt, że tego rodzaju mobilna działalność jest prowadzona głównie przez młode kobiety, dodatkowo naraża je na różne formy przemocy, w tym seksualnej (zob. Singh i in. 2012). Z kolei w Hampi, które jest mniej opłacalne pod względem potencjalnych zysków, ale i znacznie tańsze, jeśli chodzi o koszty najmu i życia, kobiety te mogły sobie pozwolić na wynajem niewielkich lokali i prowadzenie bardziej stabilnej, bezpiecznej działalności.

Podobne opinie wyrażano w odniesieniu do innych kierunków turystycznych głównego nurtu w Indiach. Zwłaszcza sezonowi migranci z Radżastanu zapytani, dlaczego zdecydowali się podróżować tak daleko - blisko półtora tysiąca kilometrów - od swoich rodzinnych miejscowości zamiast robić interesy w jednym $\mathrm{z}$ wielu popularnych wśród zagranicznych turystów radżasthańskich miast, twierdzili, że wysokie koszty najmu lokali w połączeniu z działalnością lokalnej „mafii” zmusiłyby ich do znacznego zawyżania cen, czego nie chcieli robić, bo uważali to za niemoralne.

\section{Dobre życie}

Edward F. Fischer (2014), który w swojej książce skupia się na związku między dobrym życiem a praktykami ekonomicznymi, będąc dla mnie adekwatnym punktem odniesienia w bogatej literaturze antropologicznej poświęconej kategorii dobrego życia i dobrostanu (zob. np. Calestani 2009; Mathews, Izquierdo 2009; 
Jackson 2011), wyróżnia następujące cechy dobrego życia: aspiracje i możliwości, "godność i sprawiedliwość oraz wzgląd na wyższe cele" (Fischer 2014: 5). Drobni przedsiębiorcy nieformalnego sektora turystycznego w Hampi wiązali dobre życie z możliwością sprawowania kontroli nad prowadzonym przez siebie biznesem, nawet jeśli miało to oznaczać niższe zyski. Mieli rozeznanie w dostępnych możliwościach - strukturach możliwości - i podejmowali wybory kierowane potrzebami, których nie można sprowadzić do maksymalizacji zysku. W ich rozumienie rynku i ekonomii wkradało się więc pojęcie moralności - dobra praca to taka, która pozwalała na prowadzenie uczciwego biznesu, nawet jeśli oznaczał on mniejsze korzyści materialne. Nie chodziło zatem o to, żeby mieć „więcej”, ale żeby mieć „wystarczająco” (Fischer 2014: 202). W pojęciu spokoju, którym operowali drobni przedsiębiorcy, ważne było poczucie własnej wartości potwierdzane przez budowanie partnerskich relacji międzyludzkich, które - choć rozwijane z klientami i właścicielami lokali - miały charakter również pozarynkowy. Nadawali oni „moralne znaczenie swoim rynkowym interakcjom, jednocześnie czerpiąc z nich moralne znaczenia" (Fischer 2014: 5). Bycie traktowanymi na równi, a nie jako dostarczyciele usług czy migranci-Inni, stanowiło dla nich istotne źródło osobistej godności.

W tym kontekście nie chodzi jednak o tworzenie wyidealizowanych obrazów dobra, gdyż dążenie do dobrego życia często pociąga za sobą

[...] żmudną pracę stawania się [becoming], podejmowania prób życia życiem, które uważa się za wartościowe, stawania się osobą, którą pragnie się być. W tym sensie dobre życie nie składa się ze zwykłego szczęścia, gdyż wymaga kompromisów i nierzadko rezygnacji z hedonistycznej przyjemności (Fischer 2014: 5).

Pragnienie dobrego życia jest motywowane zarówno nadziejami, jak i lękami, które w przypadku migrantów pracujących w sektorze turystycznym w Hampi uosabia kapitalistyczna dżungla na Goa. Tamtejsze ograniczające struktury możliwości były powodem, dla którego drobni przedsiębiorcy migranci wybierali Hampi, oferujące możliwości bezpiecznego, godnego i uczciwego życia.

Dobre życie nie jest kategorią elitystyczną. Arjun Appadurai (2013), na podstawie badań partycypacyjnych $\mathrm{z}$ aktywistami i mieszkańcami slumsów w Mumbaju, twierdzi, że ludzie mają "zdolność do aspirowania” (the capacity to aspire), której nie można wiązać wyłącznie z osobami należącymi do klas uprzywilejowanych. Owa zdolność jest motorem ich sprawczości, wyznaczając kroki odtąddotąd kulturowymi i etycznymi wizjami przyszłości (np. przyszłego dobrego życia). Opowiada się on za „etyką możliwości” ((ethics of possibility), która może „stworzyć bardziej inkluzywną platformę dla poprawy jakości życia w skali całej planety i pomieścić w sobie wielość wizji dobrego życia" (Appadurai 2013: 299300). A te wizje zawsze są osadzone w konkretnym czasie i miejscu (Fischer 2014: xi). Czyni tak na przykład Srocha Mahony w książce Searching for a Better Life. Growing Up in the Slums of Bangkok (2018), poświęconej mieszkańcom slumsów 
w Bangkoku, którzy starają się stworzyć lepsze życie dla siebie i swoich rodzin wbrew wszelkim przeciwnościom. Podobne stanowisko w odniesieniu do studiów migracyjnych możemy znaleźć w książce pod redakcją Anne Sigfrid Grønseth zatytułowanej Being Human, Being Migrant. Senses of Self and Well-Being (2013).

Zmiany, jakie zachodzą w Hampi w kontekście "przestrzennego czyszczenia” i przekierowywania ruchu turystycznego do dużych, sformalizowanych hoteli w Hospet, z których turyści mają być przywożeni na jednodniowe wycieczki objazdowe po ruinach, pokazuje temporalność kategorii dobrego życia. Polityka państwa realizowana pod szyldem ochrony narodowego dziedzictwa kulturowego oraz profesjonalizacji i standaryzacji oferty turystycznej, prawdopodobnie doprowadzi do końca spokoju w Hampi. Sezonowi migranci będą zmuszeni do poszukania nowych miejsc do prowadzenia biznesu. W czasie, gdy kończyłam swoje badania, niektórzy z nich już decydowali się na taki krok, wybierając inne miejscowości zorganizowane wokół świątyń. Większość jednak kontynuowała przyjazdy do Hampi, mimo liminalności i niepewności sytuacji, licząc - podobnie jak pozostali mieszkańcy - że jednak uda się ocalić resztki nieformalnego sektora we wiosce. Tak jak mieszkańcy jednak, z obawą oczekiwali zmian, co tym bardziej nadawało ich narracjom o Hampi i jego spokoju nostalgicznego wymiaru.

\section{Podsumowanie}

Sezonowi, mobilni, drobni przedsiębiorcy nieformalnego sektora turystycznego w Hampi, którzy - jako migranci na globalnym Południu - są kojarzeni przede wszystkim z czysto ekonomicznymi wyborami w podejmowaniu decyzji migracyjnych, wskazywali spokój, a nie maksymalizację zysków jako ich główną motywację. Co więcej, używali tej kategorii, aby sprzeciwić się kapitalistycznym znaczeniom korzyści płynących z pracy w turystyce, nie odrzucając ich całkowicie, ale redefiniując je za pomocą aspektów nierynkowych, które wydawały się być najważniejszym źródłem satysfakcji, jakie z tej pracy czerpali. Kategorię shanti wiązali $\mathrm{z}$ estetyką, bezpieczeństwem i moralnością: możliwością pracy $\mathrm{w}$ pięknym, spokojnym miejscu, z poczuciem zrelaksowania oraz byciem otoczonym przez miłych, przyjaznych ludzi, co tłumaczyli świętym i wiejskim charakterem miejsca. Wysoko waloryzowali również możliwość nawiązywania bliskich, partnerskich relacji z turystami, co z kolei jest cechą nieformalnego sektora turystycznego w ogóle.

Nie oznacza to bynajmniej, że powinniśmy ich po prostu sklasyfikować jako migrantów kierujących się wyborem stylu życia (lifestyle migrants). Ich mobilność jest zdecydowanie wynikiem braku możliwości zarobienia na życie swoje i swoich bliskich w rodzinnym mieście czy kraju. Jednocześnie uproszczeniem byłoby jednak ograniczenie ich wyborów i strategii dotyczących miejsca docelowego migracji do przyczyn czysto ekonomicznych. Drobni przedsiębiorcy w nieformalnym 
sektorze turystycznym łączą bowiem pracę ze stylem życia. Omówiony w artykule przypadek zarówno zatem ukazuje płynność granicy pomiędzy migracjami zarobkowymi a tymi motywowanymi wyborem stylu życia, jak i podważa dychotomię globalnego Południa i globalnej Północy wpisaną w sposób, w jaki konceptualizujemy te dwie formy mobilności. Podział ów odzwierciedla się również w dychotomii pracy i rekreacji, migracji i turystyki.

Badacze mobilności przestrzennej od jakiegoś już czasu wskazują na wzajemne powiązania między motywacjami definiowanymi tradycyjnie jako migracyjne i tymi, które zwykły być traktowane jako turystyczne, podczas gdy konceptualne granice je oddzielające nie są wcale oczywiste (zob. Hall, Williams 2002). Jedna forma mobilności przestrzennej może współistnieć z nimi: migrant czy długotrwały uchodźca bywa turystą, a turysta nierzadko podejmuje aktywności zarobkowe w trakcie podróży (Uriely 2001). Wiele napisano o turystach z krajów globalnej Północy łączących motywacje i praktyki związane z czasem wolnym i aspektem poznawczym oraz pracą najemną (Williams, Hall 2002: 5, 13; zob. też np. Mason 2002). W literaturze przedmiotu funkcjonują kategorie „pracownika migranta turysty" (migrant tourist-worker; Bianchi 2000), "pracujących turystów” (working tourists; Uriely, Reichel 2000) czy „pracujących wakacji” (working holidays; Cooper 2002). Określa się tym mianem na przykład backpackerów z Japonii, Korei Południowej i Tajwanu, którzy zatrudniają się okresowo do pracy w sektorze turystycznym u pochodzących z ich krajów, ale urodzonych bądź osiadłych w Australii i Nowej Zelandii przedsiębiorców, którzy swoją ofertę kierują do rodzimych turystów (Cooper 2002).

To, na co chciałam zwrócić uwagę $\mathrm{w}$ tym artykule, to potrzeba poszerzenia naszej ramy analitycznej poprzez uwzględnienie aspektów pozarynkowych w sposobie, w jaki myślimy o motywacjach tzw. migrantów ekonomicznych z/w krajach globalnego Południa. Poszukiwania dobrego życia nie należy traktować jako przywileju przypisywanego tylko tym, którzy należą do wyższych klas społecznych globalnej Północy, lecz jako uniwersalną potrzebę ludzką, często realizowaną za sprawą mobilności, w tym tej postrzeganej jako ekonomiczna. Jednocześnie przykład Hampi ukazuje czasowy wymiar dobrego życia, gdy zmiany o charakterze strukturalnym wprowadzane przez państwo mające na celu ograniczenie nieformalnego sektora turystycznego niszczą możliwości prowadzenia spokojnego migranckiego biznesu.

\section{Bibliografia}

Appadurai A.

2013 The Future as Cultural Fact: Essays on the Global Condition, London-New York. 2016 Moodswings in the Anthropology of the Emerging Future, https://www.journals. uchicago.edu/doi/10.14318/hau6.2.002 (dostęp: 19.11.2016). 
Ateljevic I., Doorne S.

2000 „Staying within the Fence”: Lifestyle Entrepreneurship in Tourism, „Journal of Sustainable Tourism", t. 8 (5), s. 378-392.

Benson M., O’Reilly K. (red.)

2016 Lifestyle Migration: Expectations, Aspirations and Experiences, London-New York.

Bianchi R.V.

2000 Migrant Tourist-workers: Exploring the 'Contact Zones' of Post-industrial Tourism, „Current Issues in Tourism”, t. 3 (2), s. 107-187.

Bloch N.

2016 Evicting Heritage: Spatial Cleansing and Cultural Legacy at the Hampi UNESCO Site in India, „Critical Asian Studies”, t. 48 (4), s. 556-578.

2017a Barbarians in India: Tourism as Moral Contamination, „Annals of Tourism Research", t. 62, s. 64-77.

2017b Taxonomic Panic and the Art of „Making Do” at a Heritage Site: The Case of Hampi UNESCO Site, India, „Anthropological Notebooks”, t. 23 (3), s. 19-44.

2018 Bliscy nieznajomi. Turystyka i przezwyciężanie podporzadkowania w postkolonialnych Indiach, Poznań.

Burman J.J.R.

2010 Ethnography of a Denotified Tribe: The Laman Banjara, New Delhi.

Calestani M.

2009 An Anthropology of 'The Good Life' in the Bolivian Plateau, „Social Indicators Research", t. 90, s. 141-153.

Carlsen J., Morrison A., Weber P.

2008 Lifestyle Oriented Small Tourism Firms, „Tourism Recreation Research”, t. 33 (3), s. $255-263$.

Clifford J.

1992 Travelling Cultures, w: L. Grossberg, C. Nelson, P. Treichler (red.), Cultural Studies, London-New York, s. 96-116.

Coates J.

2017 Idleness as Method: Hairdressers and Chinese Urban Mobility in Tokyo, w: A. Elliot, R. Norum, N. B. Salazar (red.), Methodologies of Mobility: Ethnography and Experiment, New York-Oxford, s. 109-128.

Cohen E.

1982 The Pacific Islands from Utopian Myth to Consumer Product: The Disenchantment of Paradise, Aix-en-Provence.

Cooper M.J.

2002 Flexible Labour Markets, Ethnicity and Tourism-related Migration in Australia and New Zealand, w: C.M. Hall, A. Williams (red.), Dordrecht, Tourism and Migration: New Relationships between Production and Consumption, s. 73-86.

Dann G.

1996 The People of Tourist Brochures, w: T. Selwyn, (red.), The Tourist Image: Myths and Myth Making in Tourism, Chichester, s. 61-82.

Das A.K.

1996 Preliminary Findings on Divine and Royal Themes in the Chariot Festival at Hampi w: D.V. Devaraj, C.S. Patil (red.), Vijayanagara: Progress of Research: 1988-1991, Mysore, s. 210-215. 
Edensor T.

1998 Tourists at the Taj: Performance and Meaning at a Symbolic Site, London-New York.

Fischer E.F.

2014 The Good Life: Aspiration, Dignity, and the Anthropology of Wellbeing, Stanford.

Fritz J.M., Michell G.

1991 City of Victory: Vijayanagara, the Medieval Hindu Capital of Southern India, New York.

2014 Hampi Vijayanagara, Mumbai.

Ghodsee K.

2005 The Red Riviera. Gender, Tourism, and Postsocialism on the Black Sea, DurhamLondon.

Gillen J.

2011 Off the Record: Segmenting Informal Discussions into Viable Methodological Categories, w: C.M. Hall (red.), Fieldwork in Tourism: Methods, Issues and Reflections, London-New York, s. 199-208.

Glick Schiller N., Irving A. (red.)

2014 Whose Cosmopolitanism? Critical Perspectives, Relationalities and Discontents, New York.

Grønseth A.S. (red.)

2013 Being Human, Being Migrant: Senses of Self and Well-being, Oxford.

Hall C.M., Williams A. (red.)

2002 Tourism and Migration: New Relationships between Production and Consumption, Dordrecht.

Herzfeld M.

2006 Spatial Cleansing: Monumental Vacuity and the Idea of the West, „Journal of Material Culture", t. 11 (1/2), s. 127-149.

Jackson M.

2011 Life within Limits: Well-being in a World of Want, Durham.

Kotraiah C.T.M.

2008 Archaeology of Hampi-Vijayanagara, Delhi.

Mahony S.

2018 Searching for a Better Life: Growing Up in the Slums of Bangkok, New YorkOxford.

Mason P.

2002 The „Big OE”: New Zealanders Overseas Experiences in Britain, w: C.M. Hall, A. Williams (red.), Tourism and Migration: New Relationships between Production and Consumption, Dordrecht, s. 87-101.

Mathews G., Izquierdo C. (red.)

2009 Pursuits of Happiness: Well-being in Anthropological Perspective, New York.

Naik D.B.

2010 The Art and Literature of Banjara Lambanis, New Delhi.

Oppermann M.

1993 Tourism Space in Developing Countries, „Annals of Tourism Research”, t. 20 (3), s. 535-556.

Ortner S.B.

2016 Dark Anthropology and Its Others: Theory Since the Eighties, „HAU: Journal of Ethnographic Theory", t. 6 (1), s. 47-73. 
Salazar N.B., Elliot A., Norum R.

2017 Studying Mobilities: Theoretical Notes and Methodological Queries, w: A. Elliot, R. Norum, N.B. Salazar (red.), Methodologies of Mobility: Ethnography and Experiment, New York-Oxford, s. 1-24.

Singh S., Repnik U., Chanchani A., Seshadri S., Viswanath R.

2012 Women Street Vendors \& Tourism: Negotiating Lives and Spaces, Bangalore.

Uriely $\mathrm{N}$.

2001 'Travelling Workers' and 'Working Tourists': Variations across the Interaction between Work and Tourism, „International Journal of Tourism Research”, t. 3, s. 1-8.

Uriely N., Reichel A.

2000 Working Tourists and Their Attitudes to Hosts, „Annals of Tourism Research”, t. 27 (2), s. 267-283.

Verghese A.

2002 Hampi: Monumental Legacy, New Delhi.

Williams A., Hall C.M.

2002 Tourism, Migration, Circulation and Mobility: The Contingencies of Time and Place, w: C.M. Hall, A. Williams (red.), Tourism and Migration: New Relationships between Production and Consumption, Dordrecht, s. 1-52.

Wilson D.

1997 Strategies for Sustainability: Lessons from Goa and the Seychelles, w: M.J. Stabler (red.), Tourism and Sustainability: Principles to Practice, New York-Wallingford, s. 173-197. 